\title{
Cardiolipin IgA Antibody Measurement
}

National Cancer Institute

\section{Source}

National Cancer Institute. Cardiolipin IgA Antibody Measurement. NCI Thesaurus. Code C122112.

The determination of the amount of cardiolipin IgA antibody in a biological specimen. 